\title{
Corrigendum: The Language of Gángan, a Yorùbá Talking Drum
}

\author{
Samuel Kayode Akinbo* \\ Department of Linguistics, University of British Columbia, Vancouver, BC, Canada \\ Keywords: tone, syllable, music, language, talking drum, Yoruba, speech surrogate
}

\section{A Corrigendum on}

\section{The Language of Gángan, a Yorùbá Talking Drum}

by Akinbo, S. K. (2021). Front. Commun. 6:650382. doi: 10.3389/fcomm.2021.650382

In the original article, there were several errors. In the Abstract, certain words were omitted accidentally from the following sentence: "To conclude, Yorùbá drummers communicate via the gángan drum by transposing certain and maybe phonological conditions of their language to musical forms."

A correction has been made to the Abstract:

"It is widely known that Yorùbá drummers communicate through their native drums. This paper investigates the grammar of gángan, which belongs to a family of Yoruba drums called dùndún. The results of this study show that Yorùbá drummers represent the phonetic realisation of lexical and grammatical tones of their language with the drum. Statistically, the speech tones and the acoustic correlate of the corresponding drum representations have a significant positive relationship. In both spoken and drum communication, vowel (V) and consonant-vowel (CV) prosodic units have different statuses. To conclude, Yorùbá drummers communicate via the gángan drum by transposing certain phonemic features and maybe phonological conditions of their language to musical forms."

In addition, "/bájo' / 'Báyọ̀ (a name)" should have been "/báj’̀ "Báyọ̣" (a name)", "ilú "city"” should have been "/ilú/ "city"', and "/ilúl/ "puncher"” should have been "/ilu/ "puncher"”.

A correction has been made to section 2 Background on Yorùbá Sound Inventory, subsection 2.2 Tone in Speech, paragraph 2:

"The tone-bearing unit in the language is a mora (Akinlabi and Liberman, 2000; Pulleyblank, 2004). Initial vowels in Yorùbá do not bear an $\mathrm{H}$ tone (Akinlabi, 1985; Pulleyblank, 2004; Pulleyblank, 2009). With sequences of $\mathrm{H}-\mathrm{L}$ and L-H tones in the language, a contour tone is formed on the second tone ${ }^{3}$. However, this does not happen in H-M, M-H, L-M or M-L sequences (Ward, 1952; Akinlabi and Liberman, 1995). For example, words like /kpákò/ H-L "chewing stick" and /ilú / "city" are realised as (kpákô) H-HL and (ilú) L-LH respectively. The other relevant tonal process involves raising the pitch value of an $\mathrm{H}$ tone in a sequence of $\mathrm{H}-\mathrm{L}$ tones and lowering the pitch of an L tone in a sequence of L-H tones (Akinlabi and Liberman, 1995; Laniran and Clements, 2003). For example, the pitch of H in /bájj/ "Báyọ̀" (a name) is higher than that of $\mathrm{H}$ in /bájə/ "exit through", and the pitch value of L in /ilú/ "city" is lower than that of L in /ilu/ "puncher"."

The authors apologize for these errors and state that these do not change the scientific conclusions of the article in any way. The original article has been updated.

Received: 09 September 2021

Accepted: 10 September 2021

Published: 26 October 2021

Citation:

Akinbo SK (2021) Corrigendum: The

Language of Gángan, a Yorùbá

Talking Drum.

Front. Commun. 6:773156.

doi: $10.3389 /$ fcomm.2021.773156

Publisher's Note: All claims expressed in this article are solely those of the authors and do not necessarily represent those of their affiliated organizations, or those of the publisher, the editors and the reviewers. Any product that may be evaluated in this article, or claim that may be made by its manufacturer, is not guaranteed or endorsed by the publisher.

Copyright $\odot 2021$ Akinbo. This is an open-access article distributed under the terms of the Creative Commons Attribution License (CC BY). The use, distribution or reproduction in other forums is permitted, provided the original author(s) and the copyright owner(s) are credited and that the original publication in this journal is cited, in accordance with accepted academic practice. No use, distribution or reproduction is permitted which does not comply with these terms. 